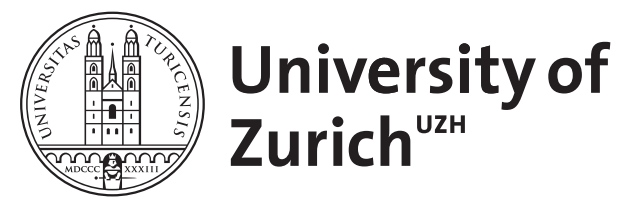

\title{
Social capital vs institutions in the growth process
}

\author{
Ahlerup, Pelle ; Olsson, Ola ; Yanagizawa-Drott, David
}

\begin{abstract}
Is social capital a substitute or a complement to formal institutions for achieving economic growth? A number of recent micro studies suggest that interpersonal trust has its greatest impact on economic performance when court institutions are relatively weak. The conventional wisdom from most macro studies, however, is that social capital is unconditionally good for growth. On the basis of the micro evidence, we outline an investment game between a producer and a lender in an incomplete-contracts setting. A key insight is that social capital will have the greatest effect on the total surplus from the game at lower levels of institutional strength and that the effect of social capital vanishes when institutions are very strong. When we bring this prediction to an empirical cross-country growth regression, it is shown that the marginal effect of social capital (in the form of interpersonal trust) decreases with institutional strength. Our results imply that a one standard deviation rise in social capital in weakly institutionalized Nigeria should increase economic growth by 1.8 percentage points, whereas the same increase in social capital only increases growth by 0.3 percentage points in strongly institutionalized Canada.
\end{abstract}

DOI: https://doi.org/10.1016/j.ejpoleco.2008.09.008

Posted at the Zurich Open Repository and Archive, University of Zurich ZORA URL: https://doi.org/10.5167/uzh-137652

Journal Article

Accepted Version

Originally published at:

Ahlerup, Pelle; Olsson, Ola; Yanagizawa-Drott, David (2009). Social capital vs institutions in the growth process. European Journal of Political Economy, 25(1):1-14.

DOI: https://doi.org/10.1016/j.ejpoleco.2008.09.008 


\title{
Social Capital vs Institutions in the Growth Process
}

\author{
Pelle Ahlerup \\ Ola Olsson \\ University of Gothenburg \\ University of Gothenburg \\ David Yanagizawa \\ Stockholm University
}

June 19, 2008

\begin{abstract}
Is social capital a substitute or a complement to formal institutions for achieving economic growth? A number of recent micro studies suggest that interpersonal trust has its greatest impact on economic performance when court institutions are relatively weak. The conventional wisdom from most macro studies, however, is that social capital is unconditionally good for growth. On the basis of the micro evidence, we outline an investment game between a producer and a lender in an incomplete-contracts setting. A key insight is that social capital will have the greatest effect on the total surplus from the game at lower levels of institutional strength and that the effect of social capital vanishes when institutions are very strong. When we bring this prediction to an empirical cross-country growth regression, it is shown that the marginal effect of social capital (in the form of interpersonal trust) decreases with institutional strength. Our results imply that a one standard deviation rise in social capital in weakly institutionalized Nigeria should increase economic growth by 1.8 percentage points, whereas the same increase in social capital only increases growth by 0.3 percentage points in strongly institutionalized Canada.
\end{abstract}

\section{Introduction}

Research on the impacts of social capital and formal institutions on economic development have so far mainly emerged as two distinct fields. In the former literature, trust, networks, social norms, and associational activity are believed to be central aspects of successful economies. In the institutional literature, formal rules of the game such as property rights laws and the strength of courts are regarded as critical for development. We argue that there is an important disconnection between results from micro studies of social capital - which indicate 
that various self enforcement mechanisms are more prevalent when contracting institutions are weak - and macro studies where social capital-related measures are hypothesized to have a uniform positive impact on economic performance.

In this article, we outline a unified theoretical framework of the relative importance of social capital and formal institutions in a simple principal-agent investment model featuring a producer and a lender in an incomplete contractsetting. The probability of contract enforcement by an exogenous court is our major indicator of institutional strength and social capital enters our model as an extra 'social' or 'intrinsic' payoff to both players from acting trusting or trustworthy. The major insight from our model is that social capital tends to have its greatest positive impact on the total monetary surplus from the game (economic growth) at lower levels of institutional development and that the positive impact eventually vanishes if institutions become strong enough.

This basic prediction about substitution is then brought to the macro level and tested in a cross-country growth regression. In accordance with our hypothesis, our results show that the marginal impact of our proxy for social capital (interpersonal trust) decreases with the quality of formal institutions. More precisely, our results imply that a one standard deviation increase in social capital leads to a 1.10 percentage points increase in the growth rate among countries at the 25th percentile of institutional strength, whereas the effect among countries at the 75 th percentile of institutional strength is only 0.36 percentage points. Our results are robust to using an instrumental variables-methodology where we take into account that social capital and institutions might be endogenous to growth or indeed have a causal impact on each other.

Our approach combines two major types of building blocks: (1) The literature on the macroeconomic effects of formal institutions and (2) the extensive empirical literature on the micro and macro effects of social capital. Starting with institutional economics, this tradition emphasizes how formal institutions such as those regulating the strength of property rights, the constraints against the executive, and the power of courts are fundamental determinants of long-run growth. Following in the footsteps of Douglass North (1981, 1990), a number of seminal contributions have emerged over the recent decade such as Knack and Keefer (1995), Hall and Jones (1999), Acemoglu et al (2001, 2002), Acemoglu and Johnson (2005), and Banerjee and Iyer (2005). These studies all show that good formal institutions are strongly associated with prosperity, although joint endogeneity problems are still an important econometric issue in the literature. Unlike our study, this literature also aims at explaining why some countries 
have better formal institutions than others. None of these studies, however, attempt to quantify the effect of informal institutions such as social networks or interpersonal trust. Acemoglu and Johnson (2005) differentiate between court ('contracting') and property rights institutions, but do not study the impact of private enforcement mechanisms.

Social capital is arguably one of the most elusive concepts in social science. As discussed by Bjornskov (2006), there are at least three important dimensions of social capital: Generalized trust, social norms, and associational/network activity. In this paper, we will focus on social capital as generalized trust among people, i.e. an optimistic expectation about the behavior of fellow citizens, many of whom we do not know personally. The empirical cross-country macro literature on social trust includes seminal contributions by Knack and Keefer (1997) and Zak and Knack (2001). ${ }^{1}$ The paper most closely related to ours is Zak and Knack (2001) who regress economic growth on both levels of interpersonal trust (from World Value Surveys, WVS) and on an index of formal institutional strength in a cross-section of 41 countries, most of which are industrialized. The authors find that interpersonal trust is positively and significantly related to growth when holding formal institutions constant. However, they do not explore the possibility of non-linear effects of trust that depend on different levels of formal institutions. In a robustness analysis of Zak and Knack (2001), Beugelsdijk et al (2004) find that the results are in general fairly robust, even when including some institutions-related measures (such as religion and political instability), but that the marginal impact of trust is greater in low-trust countries. Similarly, Tabellini (2006) finds a positive effect of interpersonal trust on growth in European regions using an instrumental variable approach, but does not analyze any differential effects depending on formal institutions ${ }^{2}$.

The overall picture in the micro studies is mixed but nevertheless suggests that social capital has a larger effect on economic performance when formal institutions are weak. Table 1 shows a summary of some of the more wellknown studies. ${ }^{3}$ For instance, Bigsten et al (2000) and Fafchamps and Minten

\footnotetext{
${ }^{1}$ See Durlauf (2002) and Durlauf and Fafchamps (2004) for a critical discussion of this line of research.

${ }^{2}$ Tabellini uses data from 69 regions in 8 Western European countries and includes country fixed effects. The instruments used are literacy rate around 1880 and constraints on the executive in the years 1600-1850. However, he does not include any measures of formal institutions at the regional level. Studying data from 54 European regions, Beugelsdijk and van Schaik (2005) find that associational activity is the best predictor or growth.

${ }^{3}$ The results referred to in the table should not be thought of as having a perfect correspondence with each other or with our model since the mentioned studies all use different methodologies. We believe they still well illustrate our basic point.
} 
(2002) both confirm that social capital has a strong role when property rights and courts are working imperfectly. The main hypothesis that emerges from these micro studies is therefore that social trust and formal institutions should be primarily substitutes in the growth process at the macro level.

Our paper is not the first effort that tries to understand how micro results on trust can be translated to a macro level. Beugelsdijk (2006) argues that it is conceptually difficult to move from micro results to a macro level when it comes to social capital and that generalized trust as measured by the WVS might actually capture the quality of formal institutions, a claim that Uslaner (2008) strongly refutes. In a similar vein, Bjornskov's (2006) empirical analysis suggests that social trust has a positive impact on the quality of government, whereas Rothstein (2000) argues that it is rather good government that causes general trust. Our analysis departs from these studies by treating social trust and institutions as two distinct factors and by estimating whether they are substitutes in development, as our model predicts. Furthermore, our use of instrumental variables arguably neutralizes the concerns referred to above about the possible linkages between generalized trust and formal institutions.

In summary, we argue that our article offers two specific contributions to the literature. Firstly, our simple modelling framework rationalizes the empirical regularity from the micro level that social capital affects growth and investment mainly when institutions are relatively weak. Secondly, our article is the first one to demonstrate empirically (and with the use of IV-methods) that generalized trust and institutional quality are substitutes for growth.

The article is organized as follows. In section 2 we present the model and derive the key results for the relevance of social capital and institutions. In section 3 we display the empirical specifications and present the results. Section 4 concludes the exposition.

\section{The Model}

In order to provide an aid for thinking about the effects of institutions and social capital on growth, we present in this section a simple model of an investment game between a Lender and a Producer, inspired by the empirical literature referred to above. The purpose of the model is to provide a micro-foundation for our hypotheses regarding the interrelationships between social capital and institutions at the macro level. 
The model is a sequential, principal-agent investment game with a representative Lender and Producer and a Court as described in extensive form in Figure $1 .{ }^{4}$ We have chosen to analyze an investment problem since it is standard to regard investment as a key engine of economic growth, but similar types of situations also apply in supplier-producer and buyer-seller situations with trade credit. We also believe that this type of game is quite similar to the scenarios described in the empirical literature referred to above. The game is one of perfect information and players are assumed to be risk neutral and non-cooperative. There are no other agents in the economy.

In the initial Credit Stage, Lender chooses whether to lend the required amount of capital $k$ or not. If she chooses not to, the game ends, no production occurs, and payoffs are $u_{L}=u_{P}=0$ for Lender and Producer respectively. This is the 'autarkic' or status quo situation where agents remain in subsistence production.

\section{$<$ Figure 1 about here $>$}

In the second Contract Stage, the players have entered a market economy where a lending of $k$ units of capital has occurred and production has been undertaken. Producer considers the option of fulfilling the credit contract which would result in Producer receiving a net monetary payoff of $\pi_{P}>0$ plus a non-monetary social benefit of cooperation $s_{P}>0$, discussed further below. Likewise, Lender would in this case be repaid the credit amount $k$ and in addition get a monetary compensation $\pi_{L}>0$ and a social payoff from being trusting $s_{L}>0$. This is also the socially optimal situation in the sense that it maximizes aggregate welfare and total monetary payoffs.

The $s_{i}$-terms capture rewards stemming from the trust and trustworthiness among our representative agents. The players may or may not have a previous history of interactions and the trust they show should be regarded as generalized trust and not network-specific. These extra payoffs are a kind of social reward such as a strengthened reputation or the moral satisfaction from living up to the positive expectation of cooperation. ${ }^{5}$ The payoffs only materialize if the player in question has shown a trusting and cooperative behavior in the first and second states. If Producer reneges in the second stage, he forgoes this social

\footnotetext{
${ }^{4} \mathrm{~A}$ similar but more complex model of "trust in the shadow of the court" is provided by Brennan et al (2003).

${ }^{5}$ See for instance Brennan et al (2003), Guth and Ockenfels (2005) and Francois and Zabojnik (2005) for similar 'intrinsic rewards' from cooperation.
} 
payoff whereas Lender retains it throughout the game if she has provided the credit in the first stage and thereby proved to be a trusting person. We further assume that social payoffs are fully observable by both players.

The conventional payoffs from the investment $\pi_{P}$ and $\pi_{L}$ have been agreed upon in the contract. $\pi_{L}$ could take the form of an interest payment to Lender or indeed as profit-sharing of some form. We leave it open here what type of financing arrangement the two players have agreed upon, although we could have easily made such a choice endogenous.

The other option for Producer is to renege on the contract, by which is meant that he retains the compensation to Lender $\pi_{L}$ that was stipulated by the contract and repudiates Lender's claims to a repayment of $k$. The dispute may then end up in court in the third stage. This is the Lawsuit Stage, where the Lender decides whether to take the reneging Producer to court or not. Should the Lender choose not to go to court the Producer keeps the total monetary payoff from the project $\pi_{L}+\pi_{P}$ while we assume that he cannot benefit from the credit $k$ that he has failed to repay. ${ }^{6}$ The Lender is left with a social payoff $s_{L}$ and with a loss of his credit. ${ }^{7}$ If Lender chooses to go to court, the court will enforce the contract with a probability $\beta$, which is our indicator of the strength of contracting institutions. $\beta$ is simply meant to reflect how strong courts are and is not intended to imply any form of strategic interaction between the Court and the Producer. The cost of going to court is covered by a loser-pays-principle, according to which the losing party pays a fine of $d$ to the court. If the contract is properly enforced, Lender gets her credit in return and receives a net payoff of $\pi_{L}+s_{L}$ while Producer receives $\pi_{P}-d$.

If the contract is not enforced by the court, Producer ends up with $\pi_{L}+$ $\pi_{P}$. Lender receives no compensation and no repayment of the credit and thus receives a net utility of $-k-d+s_{L}$ from lending. Obviously, many Lenders would require some form of collateral for the loan, but for simplicity we abstract from that in this simple setting. We also leave out aspects like the degree of contract complexity or additional social costs of a negative court ruling.

Using the payoff structure above, we can easily derive the following set of solutions:

\footnotetext{
${ }^{6}$ We make this assumption so that a failure to act trustworthy is also associated with a kind of waste in terms of total monetary payoffs. This is not a critical assumption but simplifies derivations.

${ }^{7}$ Another possibility, often observed in reality, is that Lender offers a renegotiation at this point, offering Producer not to be socially disgraced, perhaps in return for the credit and a smaller part of the net surplus from the investment.
} 
Solutions: The best response strategies of the players and the SPNE of the game are determined by the following conditions:

\begin{tabular}{|c|c|c|}
\hline $\begin{array}{l}\text { Credit stage } \\
\text { (Lender) }\end{array}$ & & $\begin{array}{l}\text { Lend if any of the following conditions applies: } \\
\qquad \begin{array}{r}\text { (i) } L \equiv s_{L}+\beta\left(\pi_{L}+k+d\right)-k-d \geq 0 \\
\left(\text { ii) } s_{L}-k \geq 0\right.\end{array} \\
\text { (iii) Producer will fulfill } \\
\text { Not lend if none of (i), (ii), or (iii) applies. }\end{array}$ \\
\hline $\begin{array}{l}\text { Contract stage } \\
\text { (Producer) }\end{array}$ & & $\begin{array}{c}\text { Fulfill if } F \equiv s_{P}+\beta\left(\pi_{L}+d\right)-\pi_{L} \geq 0 \\
\text { Renege otherwise }\end{array}$ \\
\hline $\begin{array}{l}\text { Lawsuit stage } \\
\text { (Lender) }\end{array}$ & & $\begin{array}{l}\text { Not to Court if } s_{L}-k \geq 0 \text { and } \\
\beta\left(\left(\pi_{L}+k+d\right)\right)-d \leq 0 \\
\text { To Court otherwise. }\end{array}$ \\
\hline
\end{tabular}

The key expressions above are $L=L\left(s_{L}, \beta, \pi_{L}, k, d\right)$ and $F=F\left(s_{P}, \beta, \pi_{L}, d\right)$ which determine whether the socially optimal equilibrium (Lend, Fulfill) is obtained or not. Lender's willingness to lend and Producer's willingness to fulfill will increase with the social payoffs from trustworthy behavior $s_{L}$ and $s_{P}$ and from the strength of court institutions $\beta$. Social capital and institutions are substitutes in the sense that either increases in $s_{L}$ and $s_{P}$ or an increase in $\beta$ could make $L$ or $F$ positive. The size of the investment, given by $k$, affects Lender in the sense that she becomes more cautious and less willing to lend as $k$ increases. The Lender's willingness to lend will be positively associated with her investment returns $\pi_{L}$, whereas these will have a negative influence on Producer's willingness to fulfill since a higher level makes it more tempting to try to appropriate this payoff.

Disregarding all other variables for a moment and assuming that $s_{L}=s_{P}=$ $s<k$, we can write $L(s, \beta)$ and $F(s, \beta)$. Let us imagine a situation where court institutions are at a low level $\beta^{\text {low }}$ such that $L\left(s, \beta^{\text {low }}\right)<0$ and $F\left(s, \beta^{\text {low }}\right)<0$, which means that monetary payoffs are $(0,0)$. There is then a $\Delta s>0$ such that either $L\left(s+\Delta s, \beta^{\text {low }}\right)=0$ or $F\left(s+\Delta s, \beta^{\text {low }}\right)=0$, which means that Lender supplies the credit and production occurs. In other words, at low levels of $\beta$, an increase in social capital $s$ can lead to economic development. However, at a high level of court strength $\beta^{\text {high }}$ such that $L\left(s, \beta^{\text {high }}\right) \geq 0$ and $F\left(s, \beta^{\text {high }}\right) \geq 0$, the socially optimal equilibrium is already obtained and an equivalent increase 
$\Delta s$ will have no effect. Hence, social capital increases will have a stronger positive effect when institutions are weak.

As was mentioned in the introduction, we do not attempt to explain how court institutions and social capital have emerged in the first place, but we recognize that they could both be driven by the same underlying set of forces (history, geography, ethnic fractionalization, etc) and are likely to be positively correlated. ${ }^{8}$ Let us think of $s$ as being proportional to the average level of social capital in society, i.e. the total stock of interpersonal trust that has accumulated over the years. We assume that the higher the average level, the greater the payoff from acting trustworthy. Equivalently, if the average level of trust is small, people will not be expected to cooperate and the social opportunity cost of reneging $(s)$ should be relatively small.

As a further illustration of the model, we provide a numerical example in Figure 2 where we assume $\pi_{L}=\pi_{P}=3, k=2, d=1, s_{L}=s_{P}=s$. The example assumes a relatively small investment with a relatively high total payoff and a payoff/investment ratio of $\left(\pi_{L}+\pi_{P}\right) / k=6 / 2=3$. The simplification allows us to analyze the relationship between the two remaining variables in the system; the strength of court institutions $\beta$ and the social payoff $s$. The potential outcomes of this game follow from Solutions above. The A-area shows the 'input requirement set' of court strength and social capital for the (Lend, Fulfill)-equilibrium to apply. The line defined by $\beta=\frac{3-s}{4}$ shows the combinations of $\beta$ and $s$ where Producer is indifferent about reneging or fulfilling. The curve is negatively sloped and linear, indicating that in this setup social capital and formal institutions are perfect substitutes. The equivalent line for Lender is given by $\beta=\frac{3-s}{6}$ in the $s \in[0,2)$-interval. In the B-area are the combinations where the players end up in court. The area defined by $\beta \leq \frac{1}{6}$ and $s \geq 2$ makes up the C-area where Producer reneges but Lender will not go to court. Since $\beta$ and $s$ in reality tend to be correlated, it is rather unlikely that an economy could end up here. The D-area, lastly, hosts combinations where $\beta<\frac{3-s}{6}$ and $s<2$, which yields the outcome with no investment $(0,0)$.

$<$ Figure 2 about here $>$

The main point of the figure is to illustrate intuitively how the effect of an exogenous increase in social capital can depend on the level of institutional

\footnotetext{
${ }^{8}$ See for instance Congdon Fors and Olsson (2007) for a model of endogenous institutional change and Bjornskov (2006) for an empirical analysis of how social trust appears to cause good governance.
} 
strength. The four arrows in the A, B, and D-areas show equally large increases in social capital. ${ }^{9}$ In the A-area, an increase in $s$ has no effect since the players are already in the good equilibrium. This might be thought of as equivalent to a first-best outcome which would always be in place if institutions were perfect. Two arrows originate in the D-area. The lower placed arrow shows that higher social capital may not be enough to push the economy into a better equilibrium. As mentioned above, we do not think that this scenario with a very low $\beta$ and a relatively high $s$ is often observed in reality. ${ }^{10}$ The upper arrow originating in the D-area shows that beginning at a higher level of court strength can make all the difference. In the B-area, finally - where Lender supplies the credit, Producer reneges, and the contract is settled in court - an increase in social capital is very likely to lead to the good equilibrium.

In summary, the simple framework employed here gives at least three insights. First, our model has the feature that formal institutions and social capital can be substitutes in the pursuit of the growth-maximizing equilibrium. Second, the model shows that at high levels of institutional strength, social capital can be irrelevant for the 'growth outcome'. Thirdly, at low and intermediate levels of institutional strength, increases in social capital might have a positive effect on the total payoff from investment. The model thus implies that the impact of an increase in social capital should decrease with the level of institutional strength.

\section{Empirical Evidence}

Our model and overview of the micro literature indicate that the effect of social capital on economic performance is nonlinear and will depend on the quality of institutions. Likewise, the effect of institutions on economic performance will differ between low-trust countries and high-trust countries. To keep our investigation comparable to the focal papers in the literature on social capital and growth, Knack and Keefer (1997) and Zak and Knack (2001), we employ a standard cross-country Barro-style growth model. Besides comparability with previous research this has two additional advantages - we can use what may be the best proxy available for social capital, interpersonal trust from World

\footnotetext{
${ }^{9}$ We recognize that the effect of exogenous increases in institutional strength also will depend on the level of social capital.

${ }^{10}$ Such a scenario might perhaps be observed in countries where the state has more or less collapsed and where social bonding has taken its place, as in Somalia in the 1990s. Such countries will, however, not be included in our empirical analysis.
} 
Values Surveys (WVS), and yet have sufficient variation in institutional quality. The growth regression technique has well-known drawbacks (see e.g. Brock and Durlauf, 2001 and Durlauf, 2002) but it can reveal interesting patterns of correlation and the results are straightforward to interpret. To the standard package of regressors, initial income, investment, and human capital, we add social capital and institutions.

\subsection{Model and data}

The econometric models we employ will be variations on

$$
\begin{aligned}
& \left\{\begin{array}{cc}
(i) & \text { growth }_{i, 1995-2005} \\
(i i) & \text { investment rate }_{i, 2000}
\end{array}\right\} \\
& =\beta_{0}+\beta_{1} \cdot \text { initial }_{\text {income }}+\beta_{2} \cdot \text { investment prices }_{i}+\beta_{3} \cdot \text {. }_{\text {uman }} \text { capital }_{i} \\
& +\beta_{4} \cdot \text { social capital }_{i}+\beta_{5} \cdot \text {.institutions }_{i}+\beta_{6} \cdot \text { social capital }_{i} \cdot \text {. institutions }_{i} \\
& + \text { error }_{i} \text {. }
\end{aligned}
$$

Our predictions are that $\beta_{4}, \beta_{5}>0$ but $\beta_{6}<0$. Where possible we will use initial values as regressors to mitigate concerns of reversed causality. ${ }^{11}$ In our main regressions we use growth in real per capita GDP and life expectancy from the World Bank (2006a) and initial income and investment prices from Heston et al (2006). ${ }^{12}$ Interpersonal trust is coded from WVS data as the weighted share of respondents answering that "most people can be trusted" when asked "Generally speaking, would you say that most people can be trusted, or that you can't be too careful in dealing with people?".

Interpersonal trust as it appear in WVS is an imperfect measure for social capital, as discussed by for instance Beugelsdijk (2006). In our model we pick one aspect whereby social capital can affect economic performance - that individuals gain a positive utility from being trusting and acting honestly. When more people are honst and trusting, we will see a larger fraction of the respon-

\footnotetext{
${ }^{11}$ All specifications are estimated with OLS unless we explicitly state otherwise.

${ }^{12}$ By using life expectancy instead of average years of schooling like Knack and Keefer (1997) and Zak and Knack (2001) we are able to include six more countries in our sample (Bulgaria, Czech Republic, Malta, Nigeria, Romania and Russia). Temple (1999) argues, following Nuxoll (1994), that it is preferable to use national accounts data, such as the data from the World Bank, to generate growth rates and data from the Penn World Tables, i.e. Heston et al (2006), for levels. In short, the reason is that Heston et al use international prices while national account data is based on domestic prices, and hence the latter better reflect the effect on domestic agents. Our qualitative results are not affected by this use of different sources for GDP per capita.
} 
dents answering that most people can be trusted, giving the country a higher score on interpersonal trust. ${ }^{13}$

In our main specifications we use Quality of Government in 1995 from the International Country Risk Guide (ICRG) as the measure of institutional quality. Variable descriptions and descriptive statistics for the key variables used in our main specifications are presented in tables 2 and 3. Quality of Government is the average of ICRGs measures of corruption, law and order, and bureaucracy quality, all of which are arguably related to the risk and cost involved in trying to enforce a contract. Ideally, we would use a direct measure for quality of contracting institutions since this would take us even closer to our theoretical investment game, but to our knowledge no such measure is available for a large enough sample for 1995 or earlier. The World Bank's (2006b) measures for the number of procedures involved in, as well as the number of days required for, and the cost of enforcing a contract, comes very close to the concept of contracting institutions but using them creates severe problems of reverse causality. That said, in table 8 we show that our findings are robust to using these measures instead of Quality of Government.

\subsection{Results}

The central results from the growth regressions are presented in table 4. In equation (4.5) interpersonal trust and institutions enter positively and their interaction enters as negative and all three regressors are estimated with high precision. Comparing specification (4.5) with specification (4.4) and (4.2) we see that the introduction of the interaction term increases the estimated coefficients of interpersonal trust, and a straightforward interpretation is that the growthenhancing effect of more interpersonal trust when institutions are at a low level is underestimated in (4.2) and (4.4). ${ }^{14}$ The significant interaction term means

\footnotetext{
${ }^{13}$ Zak and Knack (2001) use values on interpersonal trust from as late as 1995 to explain growth between 1970 and 1992, and this raises concerns of reversed causality. Nevertheless, due to sample size considerations we are also forced to include some countries where data on interpersonal trust was not available untill in 1996 or 1997 . When available we use interpersonal trust measured between 1990 and 1995. Then we include countries where trust was measured in 1996, 1997, and between 1981-89, which gives us 8 additional countries (Bulgaria, Colombia, Dominican Republic, Pakistan, Peru, the Philippines, Uruguay, and Venezuela).

${ }^{14}$ Institutional quality and trust are correlated (a bivariate correlation of 0.72 ) and tests show that we have multicollinearity in the model. Institutional quality is even more correlated with initial income and life expectancy (0.82 and 0.89 respectively), illustrating that if we cannot simply drop variables due to high correlation. Considering that the results are fairly robust to the changes in variables and sample size we have tried high correlation should not cause too much concern.
} 
that the marginal effect of interpersonal trust will be different at different levels of institutional quality. The average growth rate in per capita GDP between 1995 and 2005 in the sample of countries included in the growth regression is 2.42 percent, with a standard deviation of 1.44 percentage points. At the 25th percentile of institutional quality the marginal effect of a one standard deviation increase in interpersonal trust is 1.10 percentage points higher annual growth in GDP/capita, while it is 0.68 percentage points higher at median institutional quality and 0.36 percentage points at the 75 th percentile. $^{15}$

The other side of the coin is that the marginal effect of an improvement in institutional quality also will depend on the level of interpersonal trust. A one standard deviation increases in institutional quality at the 25th percentile of interpersonal trust implies 1.17 percentage points higher annual growth in per capita GDP, while the corresponding figures at the median and at the 75th percentile of interpersonal trust are 0.91 and 0.53 percentage points respectively. Clearly, countries with low institutional quality have the most to gain from better social capital and countries with low levels of social capital has the most to gain from improvements in institutional quality.

To investigate the effects on investment directly the same regressors as in the growth regression are used but the investment rate from World Bank (2006a) is used as regressand. ${ }^{16}$ The result from this exercise is presented in table 5 where neither interpersonal trust nor institutions enter significantly when they are included by themselves or together. When we include both of them as well as their interaction in specification (5.5) they get the expected signs and the estimates are statistically significant. The positive effect of social capital on the investment rate is higher at lower levels of institutions, and the positive effect of institutions is higher at lower levels of social capital. The average investment rate in 2000 for the countries included in regression (5.5) is 22.31 percent of GDP, with a standard deviation of 3.93 percentage points. At the 25th percentile of institutional quality the marginal effect of a one standard deviation increase in interpersonal trust is 2.67 percentage points higher investment rate, while it is 0.63 percentage points higher at median institutional quality and 0.98 percentage points lower (sic) at the 75 th percentile. Though it is clear that

\footnotetext{
${ }^{15}$ Zak and Knack (2001) estimated that a standard deviation increase in social capital would increase annual growth by "nearly" 1 percentage point. Thus, while their estimate does not take the differential effects stemming from differences in formal institutional quality into account, it is on the same order of magnitude as ours.

${ }^{16}$ The investment rate correctly termed the gross capital formation in percent of GDP which consists of outlays on fixed assets and inventory investments.
} 
the effect will not be the same for all countries this negative figure for some countries is most likely the result of the way we structure the nonlinearity of social capital and institutions.

A one standard deviation increase in institutional quality at the 25th percentile of interpersonal trust implies 3.16 percentage points higher investment rate, while the corresponding figures at the median and at the 75 th percentile of interpersonal trust are 2.24 and 0.81 percentage points respectively. That the estimated effect on the investment rate seems too moderate to fully explain the effect on the growth rate is in perfect order. First, to assume that institutions and social capital affect growth only via more investments would be a gross oversimplification, and hence not something we would advocate. Second, the measure for investment rate is a measure of the quantity of investments rather than the potentially more important aspect of the quality of investments. It is a fairly safe assumption that we will see positive effects on growth from a higher quality of investment, such as a smaller fraction being directed to activities that are not primarily profit generating (monitoring, insurance, security, etc.).

\subsection{Robustness}

It is likely that both interpersonal trust and institutions are measured with error and may be correlated with possible omitted variables that end up in the error term. A potentially important issue that would cause the OLS estimates to be biased is that interpersonal trust, as measured by the WVS, could partly capture the quality of formal institutions, as argued by Beugelsdijk (2006). Alternatively, the OLS estimates could also be biased if interpersonal trust has a positive impact on institutional quality, as argued by Bjornskov (2006). To deal with these potential problems and at the same time allow for a larger sample, which requires including post-1997 values of interpersonal trust, we estimate specification (4.5) using Two-Stage Least Squares, 2SLS, in specifications (6.2) and (6.3) of table 6. The instruments used in (6.2) and (6.3) are British and Socialist legal origin, the distance from the equator, and the mean distance from the ocean or a navigable river (see table 2 for more information). Legal origin and distance from the equator are commonly used as instruments for institutional quality (Acemoglu and Johnson 2005; Hall and Jones 1999). To our knowledge, we are the first to use mean distance from the ocean or a navigable river as instrument for institutions or interpersonal trust.

The instruments need to be valid, i.e. only affect the dependent variable 
indirectly through their effect on the endogenous variables. In all our regressions the results of the appropriate tests for the overidentifying restrictions are always that the instruments are valid, see the notes in table 6 for test statistics used and exact results. Instruments also need to be sufficiently informative. Following the critical values in Stock and Yogo (2002) our instruments are not weak. They are not particularly strong either, wherefore we use Limited Information Maximum Likelihood (LIML) estimation, which is a more reliable estimation technique when the instruments are weak. ${ }^{17}$ Testing also rejects the exogeneity of the instrumented variables, implying that the OLS estimates will be inconsistent and that instrumental variables methods should be used.

We have the same concerns for the investment rate regressions as for the growth regressions so we reestimate specification (5.5) with IV methods in specifications (6.5) and (6.6). The magnitude of the estimated coefficients increase when we use IV methods, implying that the OLS estimates suffered from measurement error-driven attenuation bias, while a Hausman test of the instrumented variables shows that they are exogenous, implying that OLS is consistent. We present the 2SLS and LIML results for completeness.

Over time, the level of interpersonal trust is influenced by the quality of formal institutions and vice versa. Given the relative stability of interpersonal trust and quality of formal institutions, this is not likely to be a substantial econometrical problem for growth regressions over periods as short as the one we have. But, if we would estimate the effect of interpersonal trust on growth over longer periods of time we should also take into account the indirect effect it has through its effect on formal institutions. ${ }^{18}$ Since the instrumented variables are cleansed from variation stemming from these kinds of influences, also this potential problem is dealt with when we instrument for interpersonal trust and formal institutions.

In tables 7 and 8 , we use different measures for our basic variables interper-

\footnotetext{
${ }^{17}$ Stock and Yogo (2002) finds that LIML is "far superior" to 2SLS in the presence of weak instruments. When the included instruments are weak LIML estimates are median unbiased but 2SLS is not, and LIML also have more reliable confidence intervals. The rule of thumb used to indicate weak instrument is that of a first stage F-value smaller than 10 (Staiger and Stock, 1997), but this rule should only be used when there is no more than one endogenous variable. Stock and Yogo (2002) provides critical values for more cases. In their terminology we have $\mathrm{n}=3$ (three endogenous variables) and $\mathrm{K}=4$ (four instruments). In their Table 1 values for $\mathrm{n}=3$ and $\mathrm{K}<5$ are not listed, but the critical $\mathrm{F}$-value for the 2SLS bias for $\mathrm{n}=3$ and $\mathrm{K}=5$ is 6.61 , if we accept a $10 \% 2 \mathrm{SLS}$ bias compared to $15 \%$ which is used for the rule of thumb, and the value for $\mathrm{K}=4$ would be lower than this. Using this rule we do not have weak instruments, since the lowest first stage F-value in our equation (6.2) is 7.12.

${ }^{18}$ We thank an anonymous referee for pointing out the relevance of this mechanism.
} 
sonal trust and institutional quality, this time with only growth as the dependent variable. In table 7 , we use a variety of periods and sample sizes for interpersonal trust from WVS (2006). The interaction term remains negative and is significant in all specifications except in (7.6), where we have omitted the upper and lower decile observations leaving us with a quite small sample and less variation in interpersonal trust. That the coefficient for the interaction term still remains in the same region should be seen as a sign of strength of our model.

Different proxies for institutional quality are included in table 8 and the result for the interaction term is robust to using risk of expropriation 1982-97 from the PRS, quality of public institutions in 1982 from ICRG, bureaucratic delays 1972-1995 from BERI, and the number of procedures involved in, as well as the number of days, and the cost of enforcing a contract from the World Bank, as well as a linear combination of the three. We also test for measures of corruption, the social infrastructure index and government antidiversion policies from Hall and Jones (1999) and get the same results (not reported). Since the various measures are available for samples of different sizes this can also be seen as a mild test of the robustness of the results to different samples.

In table 9 , we present some of the controls for other conditioning variables that we have performed, and these include proxies for social distance (fractionalization from Alesina et al, 2003) and proximate causes of unrest (polarization from Reynal-Querol, 2006), as well as proxies for historical factors such as state antiquity from Putterman (2006), legal origin, and identity of past colonial power. The main result remains intact and the magnitudes of the estimated coefficients are remarkably stable.

Finally, is it backwardness in the form of low income, rather than weak institutions, that gives a high return to social capital? Knack and Keefer (1997) and Zak and Knack (2001) interact initial income and trust and get a significant and negative coefficient when regressing growth 1980-1992, and both growth and investment share 1970-1992 respectively. Whereas Knack and Keefer (1997) propose that this implies that trust is more needed where contracting institutions are weak (without providing any evidence that this is the mechanism that makes the interaction term negative), Zak and Knack (2001) argue that the result implies that backwardness is more of an advantage in high-trust countries.

When we interact trust with income instead of with institutions we also obtain a negative and significant interaction term. ${ }^{19}$ In an attempt to find out

${ }^{19}$ See Ahlerup et al (2007) for the details of this exercise. 
which mechanism is the stronger one, we included both the interaction of income and trust and the interaction of institutions and trust. In our growth regression the result is that neither of them enters significantly, but when investment rate is the dependent variable the interaction between trust and institutions continue to be estimited with precision. One should not overinterpret the results from this kind of exercise but a reasonable interpretation is that if anything it is the level of formal institutions rather than the level of income that matters for the effect of trust on economic performance.

\section{Concluding Remarks}

This paper provides new insights into the current debate about the roles of social capital and institutions in economic development. Arguing that there is a missing link from micro studies to macro studies of social capital, it presents a simple theoretical framework and cross-country evidence showing that the effect of social capital on economic growth, as well as on the investment rate, is nonlinear and dependent on the quality of formal institutions. More specifically, it shows that social capital matters the most when formal institutions are weak and almost ceases to matter when institutions are strong.

For example, a one standard deviation increase in social capital is estimated to increase the growth rate by 1.8 percentage points in Nigeria but only by 0.3 percentage points in Canada, which is in sharp contrast to earlier cross-country studies that argue that social capital always improves economic growth. This implies that present attempts at building social capital creates, if successful, a strong pro-growth potential for poor countries with bad institutions. Concerns have been raised that social capital is waning in the western world and that this will have economic consequences. The findings presented in this paper imply that as long as the formal institutions are kept strong, these concerns are premature. Though the Canada-Nigeria example should be regarded as an illustration, the general results are highly robust to a number of different specifications in the basic variables.

The World Bank has made large efforts at promoting better formal institutions in developing countries and also, in recent years, begun focusing on building social capital as well. Efforts aimed at building social capital is conducted in community-level projects. However, the extent to which these efforts have been successful is rather unclear (World Bank, 2005). Our results indicate 
that much could be gained by making these projects work in areas with poor institutions.

Furthermore, much of the scholarly debate evolves around social capital and formal institutions as either mainly substitutes or complements. The result of this paper suggests that the relationship is mainly about substitution. However, unlike some of the previous literature, the paper does not discuss or test for any dynamic process between the variables. The deeper determinants, as well as the evolution of the relationship over time, are still largely unresolved issues and provide potential avenues for fruitful research, both theoretical and empirical.

\section{References}

Acemoglu, D., S. Johnson and J. Robinson (2001) "The Colonial Origins of Comparative Development: An Empirical Investigation" American Economic Review 91(5): 1369-1401.

Acemoglu, D., S. Johnson and J. Robinson (2002) "Reversal of Fortune: Geography and Institutions in the Making of the Modern World Income Distribution" Quarterly Journal of Economics 117(4): 1231-94.

Acemoglu, D. and S. Johnson (2005) "Unbundling Institutions" Journal of Political Economy 113(5):949-95

Ahlerup, P., O. Olsson, and D. Yanagizawa (2007) "Social Capital vs Institutions in the Growth Process" extended working paper version available at $<$ http://www.hgu.gu.se/item.aspx?id=2465> .

Alesina, A., A. Devleeschauwer, W. Easterly, S. Kurlat, and R. Wacziarg (2003) "Fractionalization", Journal of Economic Growth, 8(2):155-94.

Banerjee, A. and Iyer (2005) "History, Institutions, and Economic Performance: The Legacy of Colonial Land Tenure Systems in India" American Economic Review 95(4): 1190-1213.

Beckmann, V. and S. Roger (2004) Courts and Contract Enforcement in Transition Agriculture: Theory and Evidence from Poland" Agricultural Economics 31: 251-63.

Beugelsdijk, S. (2006) "A note on the theory and measurement of trust in explaining differences in economic growth" Cambridge Journal of Economics 30, 371-387.

Beugelsdijk, S. and S. Smulders (2004) "Social Capital and Growth" Tilburg University, mimeo. 
Beugelsdijk, S. and A. van Schaik (2005) "Social capital and growth in European regions: an empirical test" European Journal of Political Economy 21: 301-324.

Beugelsdijk, S., H. de Groot, and A. van Schaik (2004) "Trust and economic growth: a robustness analysis" Oxford Economic Papers 56: 118-134.

Bigsten, A., P. Collier, S. Dercon, M. Fafchamps, B. Gauthier, J.W. Gunning, A. Oduro, R. Oostendorp, C. Patillo, M. Söderbom, F. Teal and A. Zeufack (2000) "Contract Flexibility and Dispute Resolution in African Manufacturing" Journal of Development Studies 36(4): 1-37.

Bjornskov, C. (2006) "The multiple facets of social capital" European Journal of Political Economy 22, 22-40.

Brennan, G., W. Guth, and H. Kliemt (2003) "Trust in the Shadow of the Courts" Journal of Institutional and Theoretical Economics 159: 16-36.

Brock, W. and S. Durlauf (2001) "Growth Empirics and Reality", The World Bank Economic Review 15(2): 229-72.

CEPII (2006) Available online at http://www.cepii.fr, <accessed 20060520>

Congdon Fors, H. and O. Olsson (2007) "Endogenous Institutional Change After Independence", forthcoming in European Economic Review.

Durlauf, S.N. (2002) "On the Empirics of Social Capital" The Economic Journal 112: 459-79.

Durlauf, S.N. and M. Fafchamps (2004) "Social Capital" forthcoming chapter in Handbook of Economic Growth.

Fafchamps, M., and B. Minten (2002) "Returns to Social Network Capital Among Traders" Oxford Economic Papers 54: 173-206.

Francois, P. and J. Zabojnik (2005) "Trust, Social Capital, and Economic Development" Journal of the European Economic Association, 3(1): 51-94.

Gallup, John L., Andrew D. Mellinger, and Jeffrey D. Sachs (2001). "Geography Datasets" available online at http://www2.cid.harvard.edu/ciddata/Geog/physfact.dta, $<$ accessed 20060516>.

Greif, A. (1993) "Contract Enforceability and Economic Institutions in Early Trade: The Maghribi Traders' Coalition" American Economic Review 83(3), 525-548.

Grootaert, C. and D. Narayan (2004) "Local institutions, Poverty and Household Welfare in Bolivia" World Development 32(7): 1179-98.

Guiso, L., P. Sapienza and L. Zingales (2004) "The Role of Social Capital in Financial Development" American Economic Review 94(3): 526-56. 
Guth, W. and A. Ockenfels (2005) "The Coevolution of Morality and Legal Institutions: An Indirect Evolutionary Approach" Journal of Institutional Economics 1(1): 155-174.

Hall, R.E., and C.I. Jones (1999) "Why Do Some Countries Produce So Much More Output Per Worker Than Others?" The Quarterly Journal of Economics 114(1): 83-116.

Heston, A., R.Summers, and B. Aten (2006) Penn World Table Version 6.2, Center for International Comparisons of Production, Income and Prices at the University of Pennsylvania, September 2006.

Johnson, S., J. McMillan, and C. Woodruff (2002) "Courts and Relational Contracts" Journal of Law, Economics, and Organization, 18(1): 221-277.

Knack, S., and P. Keefer (1995) "Institutions and Economic Performance: Cross-Country Tests Using Alternative Institutional Measures" Economics and Politics 7(3): 207-225.

Knack, S., and P. Keefer (1997) "Does Social Capital Have An Economic Payoff? A Cross-Country Investigation" Quarterly Journal of Economics 112(4): 1251-1288

Krishna, A. (2001) "Moving from the Stock of Social Capital to the Flow of Benefits: The Role of Agency." World Development 29(6): 925-43.

La Porta, R., F. Lopez-de-Silanes, A. Schleifer, and R. Vishny (1997) "Trust In Large Organizations". The American Economic Review. 87(2)333-8.

McMillan, J. and C. Woodruff (1999) "Dispute Prevention Without Courts in Vietnam" Journal of Law, Economics, and Organization 15(3): 637-58.

Miguel, E., P. Gertler, and D.I. Levine (2005) "Does Social Capital Promote Industrialization? Evidence From a Rapid Industrializer" Review of Economics and Statistics 87(4): 754-62.

North, D. (1981) Structure and Change in Economic History, W.W. Norton \& Co., New York.

North, D. (1990) Institutions, Institutional Change, and Economic Performance, Cambridge: Cambridge University Press.

Nuxoll, D. A. (1994) "Differences in Relative Prices and International Differences in Growth Rates", American Economic Review, 84(5): 1423-36.

Pritchett, L. (2001) "Comment on "Growth Empirics and Reality" by William A. Brock and Stephen N.Durlauf" The World Bank Economic Review 15(2): 273-75.

Putterman (2006), dataset available online at http://www.econ.brown.edu/fac/Louis_Putterman, $<$ accessed 20060407>. 
Reynal-Querol, Marta (2006) Available online at http://tornasol.upf.es/ reynal/data_web.htm, $<$ accessed 20061106>.

Rothstein, B. (2000) Social traps and the problem of trust, Cambridge University Press.

Staiger, Douglas and James H. Stock (1997) "Instrumental variables regression with weak instruments", Econometrica, 65(3):557-86.

Stock, James H. and Motohiro Yogo (2002) "Testing for weak instruments in linear IV regression", NBER Technical Working Paper No. 284.

Temple, J. (1999) "The New Growth Evidence" Journal of Economic Literature, 37(1):112-56.

Teorell, J., S. Holmberg, and B. Rothstein (2006) The Quality of Government Dataset, version 15, Nov06. Göteborg University: The Quality of Government Institute, Available online at http://www.qog.pol.gu.se, <accessed 20061108>.

Tabellini, G. (2006) "Culture and Institutions: Economic Development in the Regions of Europe" Bocconi University, mimeo

Uslaner, E.M. (2008) "The foundations of trust: macro and micro" Cambridge Journal of Economics 32: 289-294.

World Bank (2005) "The Effectiveness of World Bank Support for CommunityBased and -Driven Development: An OED Evaluation", avaliable online at http://www.worldbank.org/oed/cbdcdd.

World Bank (2006a) World Development Indicators Online, available online at http://www.worldbank.org, <accessed 20061106>.

World Bank (2006b) Doing Business, available online at http://www.doingbusiness.org, $<$ accessed 20061027>.

WVS (2006) World Values Survey, available online at http://www.worldvaluessurvey.org, $<$ accessed 20061106>.

Zak, P.J. and S. Knack (2001) "Trust and Growth" The Economic Journal 111(April): 295-321. 


\begin{tabular}{|c|c|c|c|c|}
\hline Author(s) & Agents & $\begin{array}{l}\text { Social Capital } \\
\text { measure(s) }\end{array}$ & $\begin{array}{l}\text { Institutional } \\
\text { measure(s) }\end{array}$ & Relevant Findings \\
\hline $\begin{array}{l}\text { Beckman and Roger } \\
\text { (2004) }\end{array}$ & $\begin{array}{l}\text { Hog farmers in two } \\
\text { Poland }\end{array}$ & $\begin{array}{l}\text { Dependence on buyer; } \\
\text { duration of business } \\
\text { relationship; buyer } \\
\text { specific investments }\end{array}$ & $\begin{array}{l}\text { Farmers' preception of } \\
\text { court strength }\end{array}$ & $\begin{array}{l}\text { Farmers are unwilling to take cases to court when the } \\
\text { measures of social capital are high }\end{array}$ \\
\hline $\begin{array}{l}\text { Beugelsdijk and } \\
\text { Smulders (2004) }\end{array}$ & $\begin{array}{l}\text { Citizens of } 54 \text { European } \\
\text { regions }\end{array}$ & $\begin{array}{l}\text { Density of associational } \\
\text { activity; importance of } \\
\text { family and friends. }\end{array}$ & None & $\begin{array}{l}\text { Bridging social capital (associational activity) is positively } \\
\text { related to economic growth whereas bonding social } \\
\text { capital ( family ties, etc) is not. }\end{array}$ \\
\hline Bigsten et al. (2000) & $\begin{array}{l}\text { Manufacturing firms in } \\
6 \text { African countries }\end{array}$ & $\begin{array}{l}\text { Length of business } \\
\text { relationship. }\end{array}$ & None & $\begin{array}{l}\text { Renegotiations of broken contracts are helped by (trust } \\
\text { creating) long-term relations. Better institutions may } \\
\text { encourage risk taking and therefore also lead to more } \\
\text { recourse to courts in case of contract breach. }\end{array}$ \\
\hline $\begin{array}{l}\text { Fafchamps and Minten } \\
\text { (2002) }\end{array}$ & $\begin{array}{l}\text { Agricultural traders in } \\
\text { Madagascar }\end{array}$ & $\begin{array}{l}\text { Number of relatives in } \\
\text { agricultural trade; } \\
\text { traders known; and } \\
\text { potential informal } \\
\text { lenders }\end{array}$ & None & $\begin{array}{l}\text { Positive effect on firm productivity for better connected } \\
\text { traders. Social capital lowers transaction costs. }\end{array}$ \\
\hline $\begin{array}{l}\text { Guiso, Sapienza and } \\
\text { Zingales (2004) }\end{array}$ & Households in Italy & $\begin{array}{l}\text { Electoral turnout, blood } \\
\text { donation and trust (as } \\
\text { measured by World } \\
\text { Value Surveys). }\end{array}$ & $\begin{array}{l}\text { Mean number of years it } \\
\text { takes to complete a } \\
\text { first-degree trial. }\end{array}$ & $\begin{array}{l}\text { More social capital implies a more frequent use of } \\
\text { checks, more investment in stocks a apposed to cash and } \\
\text { more institutional rather than informal credit. The effect } \\
\text { is stronger in areas with weaker legal enforcement. }\end{array}$ \\
\hline $\begin{array}{l}\text { Johnson, McMillan and } \\
\text { Woodruff (2002) }\end{array}$ & $\begin{array}{l}\text { Firms and customers in } \\
5 \text { East European } \\
\text { countries }\end{array}$ & Relational contracting & $\begin{array}{l}\text { Stated belief that courts } \\
\text { can enforce contracts. }\end{array}$ & $\begin{array}{l}\text { Trust-based interaction ("relational contracting") more } \\
\text { likely when institutions are weak. }\end{array}$ \\
\hline Krishna (2001) & Villages in rural India. & $\begin{array}{l}\text { An index created } \\
\text { labour-group } \\
\text { participation, } \\
\text { assessments on the } \\
\text { cooperative attitude, } \\
\text { and trust, solidarity and }\end{array}$ & $\begin{array}{l}\text { Various variables } \\
\text { measuring the agency } \\
\text { power: how strong are } \\
\text { the caste leaders; local } \\
\text { government; patron- } \\
\text { client links; political }\end{array}$ & $\begin{array}{l}\text { Social capital is beneficial for development only if it is } \\
\text { activated by agency power (i.e. needs some minimum } \\
\text { level of institutions). Social capital without agency power } \\
\text { does not help development. }\end{array}$ \\
\hline
\end{tabular}




\begin{tabular}{|l|l|l|l|l|}
\hline & reciprocity. & $\begin{array}{l}\text { parties' power; village } \\
\text { councils and the } \\
\text { capacity of young and } \\
\text { educated leaders. }\end{array}$ & \\
\hline $\begin{array}{l}\text { McMillan and Woodruff } \\
(1999)\end{array}$ & $\begin{array}{l}\text { Managers of } \\
\text { manufacturing firms in } \\
\text { Vietnam }\end{array}$ & $\begin{array}{l}\text { Percent of relationships } \\
\text { involving community } \\
\text { sanctions and networks }\end{array}$ & None & $\begin{array}{l}\text { Social capital is important since courts and private } \\
\text { property rights are weak. Loss of future business } \\
\text { opportunity is not an important sanction. Instead, } \\
\text { scrutinization of potential clients, community sanctions, } \\
\text { and renegotiation are commonly used. }\end{array}$ \\
\hline $\begin{array}{l}\text { Miguel, Gertler and } \\
\text { Levine (2005) }\end{array}$ & Districts in Indonesia & $\begin{array}{l}\text { Relative expenditures on } \\
\text { festivals and ceremonies } \\
\text { and a subjective } \\
\text { assessment on the } \\
\text { traditional level of ethic } \\
\text { and mutual cooperation. } \\
\text { A number of measures } \\
\text { of formal community } \\
\text { groups. }\end{array}$ & $\begin{array}{l}\text { None } \\
\text { industrial level of social capital does not predict subsequent }\end{array}$ \\
\hline
\end{tabular}


Table 2: Variable descriptions

\begin{tabular}{|c|c|c|}
\hline Variable Name & Variable Description & Source: \\
\hline \multicolumn{3}{|l|}{ Main variables } \\
\hline Growth & Annual growth in GDP per capita1995-2005 & World Bank (2006a) \\
\hline InitInc & Log GDP per capita (Constant Prices: Laspevres) & Heston et al. (2006) \\
\hline InvPrice & Price level of investment, PPP & Heston et al. (2006) \\
\hline LifeExp & Life expectancy at birth, total (years) & World Bank (2006a) \\
\hline Trust & Interpersonal trust in survey $1990-95+96,97,81-89$, imputed & WVS (2006) \\
\hline Inst. & Quality of government, ICRG & Teorell et al. (2006) \\
\hline \multicolumn{3}{|l|}{ Other variables } \\
\hline bri_col & British colony & CEPII (2006) \\
\hline Bureaucratic delays 1972-1995 & Bureaucratic delays 1972-1995, BERI & Teorell et al. (2006) \\
\hline $\begin{array}{l}\text { Composite contract } \\
\text { enforcement }\end{array}$ & $\begin{array}{l}\text { Composite court quality, calculated as the mean of the } \\
\text { other three measures from World Bank (2006b) }\end{array}$ & World Bank (2006b) \\
\hline $\begin{array}{l}\text { Contract enforceability } 1982- \\
89\end{array}$ & Contract enforceability, 1982-89, BERI & La Porta et al. (1997) \\
\hline Cost of contract enforcement & Cost to enforce contract (norm) in 2003 & World Bank (2006b) \\
\hline $\begin{array}{l}\text { Days for contract } \\
\text { enforcement }\end{array}$ & Time to enforce contract (norm) in 2003 & World Bank (2006b) \\
\hline Abslat & Absolute latitude in degrees & CEPII (2006) \\
\hline Distcr & Mean distance to coast or river & Gallup et al. (2001) \\
\hline esp_col & Spanish colony & CEPII (2006) \\
\hline Ethnic Fractionalization & Ethnic fractionalization & Alesina et al. (2003) \\
\hline Ethnic Polarization & (mean) ETH12POL & Reynal-Querol (2006) \\
\hline fra_col & French colony & CEPII (2006) \\
\hline InvRate & Gross capital formation in $2000(\%$ of GDP) & World Bank (2006a) \\
\hline legor_fr & French legal origin & La Porta et al. (1997) \\
\hline legor_sc & Scandinavian legal origin & La Porta et al. (1997) \\
\hline legor_so & Socialist legal origin & La Porta et al. (1997) \\
\hline legor_uk & British legal origin & La Porta et al. (1997) \\
\hline Linguistic Fractionalization & Linguistic fractionalization & Alesina et al. (2003) \\
\hline $\begin{array}{l}\text { Procedures in contract } \\
\text { enforcement }\end{array}$ & Procedures to enforce contract(norm) in 2003 & World Bank (2006b) \\
\hline prt_col & Portugese colony & CEPII (2006) \\
\hline $\begin{array}{l}\text { Quality of public institutions, } \\
1982\end{array}$ & Quality of public institutions, 1982 & Teorell et al. (2006) \\
\hline Religious Fractionalization & Religious fract. & Alesina et al. (2003) \\
\hline Religious Polarization & Rel pol & Reynal-Querol (2006) \\
\hline $\begin{array}{l}\text { Risk of Expropriation 1982- } \\
1997\end{array}$ & Risk of expropriation 1982-1997, ICRG & Glaeser et al. (2004) \\
\hline State Antiquity & State Antiquity by 1950, v3. & Putterman (2006) \\
\hline Trust (v.2) & $\begin{array}{l}\text { Interpersonal trust in survey } 1990-95+96-99,81-89 \text {, } \\
\text { imputed }\end{array}$ & WVS (2006) \\
\hline Trust (v.3) & Interpersonal trust in survey 1981-95 & WVS (2006) \\
\hline Trust (v.4) & Interpersonal trust in survey $1990-95$ & WVS (2006) \\
\hline Trust (v.5) & Interpersonal trust in survey 1981-2004 & WVS (2006) \\
\hline
\end{tabular}


Table 3: Descriptive statistics for main variables

For countries and variables in specification (4.5):

\begin{tabular}{llllll}
\hline \hline Variable & $\mathbf{N}$ & Mean & Std dev & Min & Max \\
\hline Growth & 46 & 2.42 & 1.44 & -0.36 & 7.87 \\
InitInc & 46 & 9.23 & 0.85 & 6.85 & 10.29 \\
InvPrice & 46 & 86.91 & 30.65 & 33.85 & 171.16 \\
LifeExp & 46 & 72.05 & 6.86 & 45.18 & 79.54 \\
Trust & 46 & 0.32 & 0.16 & 0.05 & 0.66 \\
Inst & 46 & 0.76 & 0.21 & 0.36 & 1.00 \\
\hline
\end{tabular}

For countries and variables in specification (5.5):

\begin{tabular}{llllll}
\hline \hline Variable & $\mathbf{N}$ & Mean & Std dev & Min & Max \\
\hline InvRate & 61 & 22.31 & 3.93 & 13.69 & 32.76 \\
InitInc & 61 & 9.28 & 0.85 & 6.98 & 10.78 \\
InvPrice & 61 & 67.06 & 23.47 & 17.63 & 137.50 \\
LifeExp & 61 & 72.89 & 6.89 & 43.78 & 81.08 \\
Trust & 61 & 0.30 & 0.14 & 0.05 & 0.66 \\
Inst & 61 & 0.68 & 0.21 & 0.31 & 1.00 \\
\hline
\end{tabular}


Table 4: Social capital, institutions, and growth 1995-2005

\begin{tabular}{|c|c|c|c|c|c|}
\hline & \multicolumn{5}{|c|}{ Dependent variable: Growth 1995-2005 } \\
\hline & $(4.1)$ & $(4.2)$ & $(4.3)$ & $(4.4)$ & $(4.5)$ \\
\hline InitInc & $\begin{array}{c}-0.280 \\
(0.34)\end{array}$ & $\begin{array}{l}-0.695 \\
(1.27)\end{array}$ & $\begin{array}{c}-1.700 \\
(2.97)^{* * *}\end{array}$ & $\begin{array}{c}-1.504 \\
(2.87)^{* * *}\end{array}$ & $\begin{array}{c}-1.608 \\
(3.31)^{* * *}\end{array}$ \\
\hline InvPrice & $\begin{array}{c}-0.016 \\
(2.69)^{* *}\end{array}$ & $\begin{array}{c}-0.024 \\
(3.12)^{* * *}\end{array}$ & $\begin{array}{c}-0.028 \\
(3.68)^{* * *}\end{array}$ & $\begin{array}{c}-0.029 \\
(4.21)^{* * *}\end{array}$ & $\begin{array}{c}-0.023 \\
(3.44)^{* * *}\end{array}$ \\
\hline LifeExp & $\begin{array}{l}0.036 \\
(0.43)\end{array}$ & $\begin{array}{l}0.024 \\
(0.43)\end{array}$ & $\begin{array}{l}0.050 \\
(0.93)\end{array}$ & $\begin{array}{l}0.039 \\
(0.79)\end{array}$ & $\begin{array}{l}0.052 \\
(1.13)\end{array}$ \\
\hline Trust & & $\begin{array}{c}6.668 \\
(5.41)^{* * *}\end{array}$ & & $\begin{array}{c}4.028 \\
(3.14)^{* * *}\end{array}$ & $\begin{array}{c}15.896 \\
(3.59)^{* * *}\end{array}$ \\
\hline Inst & & & $\begin{array}{c}8.021 \\
(5.94)^{* * *}\end{array}$ & $\begin{array}{c}5.500 \\
(3.76)^{* * *}\end{array}$ & $\begin{array}{c}8.728 \\
(4.90)^{* * *}\end{array}$ \\
\hline Trust*Inst & & & & & $\begin{array}{c}-14.143 \\
(2.78)^{* * *}\end{array}$ \\
\hline Constant & $\begin{array}{c}3.857 \\
(2.01)^{*}\end{array}$ & $\begin{array}{c}7.053 \\
(3.46)^{* * *}\end{array}$ & $\begin{array}{c}10.827 \\
(4.89)^{* * *}\end{array}$ & $\begin{array}{c}10.567 \\
(5.26)^{* * *}\end{array}$ & $\begin{array}{c}7.594 \\
(3.54)^{* * *}\end{array}$ \\
\hline $\mathrm{N}$ & 46 & 46 & 46 & 46 & 46 \\
\hline $\mathrm{R}^{2}$ & 0.15 & 0.51 & 0.54 & 0.63 & 0.70 \\
\hline
\end{tabular}

Notes: Absolute value of t-statistic in parentheses, * significant at $10 \%$; ** significant at $5 \%$; *** significant at $1 \%$. In (4.1) robust standard errors are used. In all regressions InitInc, InvPrice, and LifeExp are from 1995, while Trust is Interpersonal Trust(v.1) and Inst. is Quality of Government in 1995.

Table 5: Social capital, institutions, and the investment rate in 2000.

\begin{tabular}{|c|c|c|c|c|c|}
\hline & \multicolumn{5}{|c|}{ Dependent variable: Investment rate 2000} \\
\hline & $(5.1)$ & $(5.2)$ & (5.3) & $(5.4)$ & $(5.5)$ \\
\hline \multirow{2}{*}{ InitInc } & 0.277 & 0.122 & -0.640 & -0.639 & -1.952 \\
\hline & $(0.24)$ & $(0.10)$ & $(0.47)$ & $(0.46)$ & $(1.60)$ \\
\hline \multirow[t]{2}{*}{ InvPrice } & -0.037 & -0.038 & -0.042 & -0.042 & -0.010 \\
\hline & $(1.21)$ & $(1.25)$ & $(1.38)$ & $(1.36)$ & $(0.36)$ \\
\hline \multirow[t]{2}{*}{ LifeExp } & 0.163 & 0.164 & 0.144 & 0.144 & 0.144 \\
\hline & $(1.42)$ & $(1.42)$ & $(1.25)$ & $(1.23)$ & $(1.44)$ \\
\hline \multirow[t]{2}{*}{ Trust } & & 1.865 & & -0.142 & 55.616 \\
\hline & & $(0.44)$ & & $(0.03)$ & $(4.33) * * *$ \\
\hline \multirow[t]{2}{*}{ Inst } & & & 5.414 & 5.475 & 30.728 \\
\hline & & & $(1.19)$ & $(1.10)$ & $(4.39) * * *$ \\
\hline \multirow[t]{2}{*}{ Trust*Inst } & & & & & -73.752 \\
\hline & & & & & $(4.56)^{* * *}$ \\
\hline \multirow[t]{2}{*}{ Constant } & 10.352 & 11.202 & 16.927 & 16.936 & 9.491 \\
\hline & $(1.57)$ & $(1.62)$ & $(1.97)^{*}$ & $(1.96)^{*}$ & $(1.25)$ \\
\hline $\mathrm{N}$ & 61 & 61 & 61 & 61 & 61 \\
\hline $\mathrm{R}^{2}$ & 0.08 & 0.08 & 0.10 & 0.10 & 0.35 \\
\hline
\end{tabular}


Table 6: IV-estimations for Growth 1995-2005 and Investment Rate 2000.

\begin{tabular}{lcccccc}
\hline \hline & \multicolumn{2}{c}{ Dependent variable: Growth } & $1995-2005$ & \multicolumn{2}{c}{ Dependent variable: Investment rate 2000 } \\
\cline { 2 - 7 } & OLS & 2 SLS & LIML & OLS & 2 SLS & LIML \\
& $(6.1)$ & $(6.2)$ & $(6.3)$ & $(6.4)$ & $(6.5)$ & $(6.6)$ \\
\hline InitInc & -0.452 & -1.224 & -1.412 & -1.952 & -1.820 & -1.941 \\
& $(0.61)$ & $(0.82)$ & $(0.73)$ & $(1.60)$ & $(0.95)$ & $(0.95)$ \\
InvPrice & -0.036 & -0.010 & 0.001 & -0.010 & 0.014 & 0.018 \\
& $(4.00)^{* * *}$ & $(0.40)$ & $(0.04)$ & $(0.36)$ & $(0.36)$ & $(0.44)$ \\
LifeExp & -0.014 & 0.009 & 0.023 & 0.144 & 0.148 & 0.149 \\
& $(0.18)$ & $(0.08)$ & $(0.15)$ & $(1.44)$ & $(1.29)$ & $(1.26)$ \\
Trust & 20.656 & 81.121 & 102.852 & 55.616 & 79.729 & 86.135 \\
& $(5.23)^{* * *}$ & $(2.39)^{* *}$ & $(2.09)^{* *}$ & $(4.33)^{* * *}$ & $(1.91)^{*}$ & $(1.85)^{*}$ \\
Inst & 7.466 & 28.040 & 35.223 & 30.728 & 41.577 & 44.549 \\
& $(2.82)^{* * *}$ & $(1.87)^{*}$ & $(1.68)^{*}$ & $(4.39)^{* * *}$ & $(1.98)^{*}$ & $(1.91)^{*}$ \\
Trust*Inst & -20.445 & -95.135 & -122.915 & -73.752 & -112.338 & -121.241 \\
& $(4.02)^{* * *}$ & $(2.16)^{* *}$ & $(1.93)^{*}$ & $(4.56)^{* * *}$ & $(2.06)^{* *}$ & $(1.98)^{*}$ \\
Constant & 4.369 & -7.798 & -13.162 & 9.491 & 0.400 & -0.755 \\
& $(1.40)$ & $(0.69)$ & $(0.84)$ & $(1.25)$ & $(0.03)$ & $(0.05)$ \\
$\mathrm{N}$ & 61 & 60 & 60 & 61 & 60 & 60 \\
$\mathrm{R}^{2}$ & 0.46 & $\mathrm{a}$ & $\mathrm{a}$ & 0.35 & $\mathrm{a}$ & $\mathrm{a}$ \\
\hline
\end{tabular}

Notes: a In 2SLS and LIML the $\mathrm{R}^{2}$ has no statistical meaning and is omitted from the table. Absolute value of t-statistic in parentheses, * significant at 10\%; ** significant at 5\%; *** significant at 1\%. In (6.1) robust standard errors are used. In (6.1), (6.2), and (6.2) InitInc, InvPrice, and LifeExp are from 1995. In (6.4), (6.5), and (6.6 ) InvRate, InitInc, InvPrice, and LifeExp are from 2000. Trust is Interpersonal Trust(v.2) and Inst. is Quality of Government in 2000. Instrumented variables are: Trust, Inst, and Trust*Inst. Instruments are: legor_uk legor_so abslat distcr. In the case of 2SLS the appropriate test for the validity of the instruments is the Sargan test statistic which his has the null hypothesis that the instruments are not correlated with the error term of the second stage and therefore that the excluded instruments are correctly excluded from the regression. Failure to reject the null implies that the instruments are valid. For LIML, a corresponding test is the Anderson-Rubin test of overidentifying restrictions.Spec (6.2): First stage Fvalues are 11.90 for Trust, 7.12 for Inst, and 12.05 for Trust*Inst. Sargan's test of overidentification of all instruments: P-value $=0.18472$. Wu-Hauman test for exogenous regressors: P-value $=0.00346$. Spec (6.3): First stage F-value: same as (6.2). Anderson-Rubin's test of overidentification of all instruments, P-value= 0.23032. Spec (6.5): First stage Fvalues are 9.10 for Trust, 6.91 for Inst, and 9.94 for Trust*Inst. Sargan's test of overidentification of all instruments: Pvalue $=0.27626$. Wu-Hauman test for exogenous regressors: P-value $=0.40179$. Spec (6.6): First stage F-value: same as (6.5). Anderson-Rubin's test of overidentification of all instruments, P-value $=0.27951$. 
Table 7: Controlling for alternative samples and measures of social capital

\begin{tabular}{|c|c|c|c|c|c|c|}
\hline & \multicolumn{6}{|c|}{ Dependent variable: Growth 1995-2005 } \\
\hline & $\begin{array}{c}\text { Full } \\
\text { Sample } \\
(7.1)\end{array}$ & $\begin{array}{c}\text { Full } \\
\text { Sample } \\
(7.2)\end{array}$ & $\begin{array}{c}\text { Full } \\
\text { Sample } \\
(7.3)\end{array}$ & $\begin{array}{c}\text { Full } \\
\text { Sample } \\
(7.4)\end{array}$ & $\begin{array}{c}\text { Omit if } \\
\text { Trust }<\text { p10 } \\
(7.5)\end{array}$ & $\begin{array}{c}\text { Omit if } \\
\text { Trust }<\mathrm{p} 10 \text { or } \\
\text { Trust }>\mathrm{p} 90 \\
(7.6)\end{array}$ \\
\hline InitInc & $\begin{array}{c}-1.392 \\
(2.98)^{* * *}\end{array}$ & $\begin{array}{c}-1.465 \\
(3.05)^{* * *}\end{array}$ & $\begin{array}{c}-1.475 \\
(3.06)^{* * *}\end{array}$ & $\begin{array}{c}-1.318 \\
(2.72)^{* * *}\end{array}$ & $\begin{array}{c}-1.416 \\
(2.87)^{* * *}\end{array}$ & $\begin{array}{l}-1.207 \\
(2.00)^{*}\end{array}$ \\
\hline InvPrice & $\begin{array}{c}-0.022 \\
(3.24)^{* * *}\end{array}$ & $\begin{array}{c}-0.024 \\
(3.66)^{* * *}\end{array}$ & $\begin{array}{c}-0.024 \\
(3.61)^{* * *}\end{array}$ & $\begin{array}{c}-0.023 \\
(3.16)^{* * *}\end{array}$ & $\begin{array}{c}-0.022 \\
(3.42)^{* * *}\end{array}$ & $\begin{array}{c}-0.022 \\
(3.15)^{* * *}\end{array}$ \\
\hline LifeExp & $\begin{array}{l}0.035 \\
(0.81)\end{array}$ & $\begin{array}{l}0.047 \\
(1.05)\end{array}$ & $\begin{array}{l}0.044 \\
(0.97)\end{array}$ & $\begin{array}{l}0.037 \\
(0.82)\end{array}$ & $\begin{array}{l}0.039 \\
(0.83)\end{array}$ & $\begin{array}{l}0.026 \\
(0.48)\end{array}$ \\
\hline Inst & $\begin{array}{c}9.790 \\
(5.51)^{* * *}\end{array}$ & $\begin{array}{c}8.324 \\
(3.20)^{* * *}\end{array}$ & $\begin{array}{c}8.684 \\
(3.46)^{* * *}\end{array}$ & $\begin{array}{c}10.128 \\
(5.37)^{* * *}\end{array}$ & $\begin{array}{c}10.246 \\
(4.45)^{* * *}\end{array}$ & $\begin{array}{c}8.728 \\
(2.61)^{* *}\end{array}$ \\
\hline Trust & $\begin{array}{c}17.438 \\
(3.75)^{* * *}\end{array}$ & $\begin{array}{c}16.868 \\
(2.59)^{* *}\end{array}$ & $\begin{array}{c}17.083 \\
(2.68)^{* *}\end{array}$ & $\begin{array}{c}17.755 \\
(3.33)^{* * *}\end{array}$ & $\begin{array}{c}22.573 \\
(3.11)^{* * *}\end{array}$ & $\begin{array}{l}17.771 \\
(1.79)^{*}\end{array}$ \\
\hline Trust*Inst & $\begin{array}{c}-17.105 \\
(3.24)^{* * *}\end{array}$ & $\begin{array}{c}-15.094 \\
(2.04)^{*}\end{array}$ & $\begin{array}{l}-15.428 \\
(2.16)^{* *}\end{array}$ & $\begin{array}{l}-17.948 \\
(2.95)^{* * *}\end{array}$ & $\begin{array}{c}-21.229 \\
(2.75) * * *\end{array}$ & $\begin{array}{c}-16.203 \\
(1.46)\end{array}$ \\
\hline Constant & $\begin{array}{c}6.244 \\
(2.81)^{* * *}\end{array}$ & $\begin{array}{c}6.966 \\
(2.60)^{* *}\end{array}$ & $\begin{array}{c}7.047 \\
(2.66)^{* *}\end{array}$ & $\begin{array}{c}5.351 \\
(2.16)^{* *}\end{array}$ & $\begin{array}{c}5.244 \\
(1.95)^{*}\end{array}$ & $\begin{array}{c}5.604 \\
(1.80)^{*}\end{array}$ \\
\hline $\begin{array}{l}\text { Trust } \\
\text { (version) }\end{array}$ & (v.2) & (v.3) & (v.4) & (v.5) & (v.1) & (v.1) \\
\hline $\mathrm{N}$ & 51 & 38 & 37 & 51 & 40 & 34 \\
\hline $\mathrm{R}^{2}$ & 0.66 & 0.73 & 0.73 & 0.64 & 0.71 & 0.54 \\
\hline
\end{tabular}

Notes: Absolute value of $\mathrm{t}$ statistics in parentheses, ${ }^{*}$ significant at $10 \%$; ** significant at $5 \%$; *** significant at $1 \%$. In all regressions InitInc, InvPrice, and LifeExp are from 1995, Inst. is Quality of Government in 1995, while Trust is Interpersonal Trust (v.x). See variable description for exact coding. Trust $>\mathrm{p} 10$ means that countries with a trust value less than the $10^{\text {th }}$ percentile is removed from the sample. 
Table 8: Controlling for alternative measures of institutional quality

\begin{tabular}{|c|c|c|c|c|c|c|c|c|}
\hline & \multicolumn{8}{|c|}{ Dependent variable: Growth 1995-2005 } \\
\hline & $(8.1)$ & $(8.2)$ & $(8.3)$ & $(8.4)$ & $(8.5)$ & $(8.6)$ & $(8.7)$ & $(8.8)$ \\
\hline \multirow[t]{2}{*}{ InitInc } & -1.525 & -1.057 & -0.494 & -1.048 & -3.400 & -2.818 & -3.306 & -3.446 \\
\hline & $(2.64)^{* *}$ & $(1.36)$ & $(0.59)$ & $(1.27)$ & $(3.83)^{* * *}$ & $(5.23)^{* * *}$ & $(3.48)^{* * *}$ & $(6.68)^{* * *}$ \\
\hline \multirow[t]{2}{*}{ InvPrice } & -0.017 & -0.015 & -0.029 & -0.016 & 0.003 & 0.003 & -0.000 & 0.003 \\
\hline & $(2.35) * *$ & $(1.72)^{*}$ & $(2.58)^{* *}$ & $(1.58)$ & $(0.18)$ & $(0.33)$ & $(0.01)$ & $(0.35)$ \\
\hline \multirow[t]{2}{*}{ LifeExp } & 0.041 & 0.050 & -0.005 & 0.028 & 0.212 & 0.206 & 0.241 & 0.220 \\
\hline & $(0.80)$ & $(0.80)$ & $(0.08)$ & $(0.35)$ & $(2.58)^{* *}$ & $(2.95)^{* * *}$ & $(2.41)^{* *}$ & $(3.58)^{* * *}$ \\
\hline \multirow[t]{2}{*}{ Trust } & 21.225 & 17.783 & 23.124 & 16.947 & 5.751 & 5.895 & 5.032 & 5.150 \\
\hline & $(2.41)^{* *}$ & $(3.91)^{* * *}$ & $(4.00)^{* * *}$ & $(2.57)^{* *}$ & $(3.74)^{* * *}$ & $(2.22)^{* *}$ & $(3.01)^{* * *}$ & $(2.33)^{* *}$ \\
\hline \multirow[t]{2}{*}{ Inst } & 0.983 & 0.417 & 1.060 & 1.896 & 1.821 & 1.969 & 2.049 & 3.762 \\
\hline & $(3.44)^{* * *}$ & $(1.79)^{*}$ & $(2.74)^{* *}$ & $(1.66)$ & $(4.33) * * *$ & $(2.03)^{* *}$ & $(4.63) * * *$ & $(4.19)^{* * *}$ \\
\hline \multirow[t]{2}{*}{ Trust*Inst } & -1.834 & -1.469 & -3.151 & -4.455 & -3.835 & -5.901 & -4.543 & -8.141 \\
\hline & $(1.88)^{*}$ & $(2.71)^{* *}$ & $(3.17)^{* * *}$ & $(1.83)^{*}$ & $(3.02)^{* * *}$ & $(1.76)^{*}$ & $(3.53)^{* * *}$ & $(2.80)^{* * *}$ \\
\hline \multirow[t]{2}{*}{ Constant } & 5.202 & 4.857 & 2.725 & 5.104 & 17.162 & 12.403 & 14.758 & 17.383 \\
\hline & $(1.72)^{*}$ & $(1.41)$ & $(1.08)$ & $(1.33)$ & $(3.89)^{* * *}$ & $(3.65)^{* * *}$ & $(3.47)^{* * *}$ & $(4.87)^{* * *}$ \\
\hline Trust (version) & (v.1) & (v.1) & (v.1) & (v.1) & (v.5) & (v.5) & (v.5) & (v.5) \\
\hline $\begin{array}{l}\text { Institutional } \\
\text { Measure }\end{array}$ & $\begin{array}{c}\text { Risk of } \\
\text { Expropriation, } \\
1982-1997\end{array}$ & $\begin{array}{c}\text { Quality of Public } \\
\text { Institutions, } \\
1982\end{array}$ & $\begin{array}{c}\text { Bureaucratic } \\
\text { delays, } 1972 \text { - } \\
1995\end{array}$ & $\begin{array}{c}\text { Contract } \\
\text { Enforceability, } \\
1972-1989\end{array}$ & $\begin{array}{l}\text { Cost of contract } \\
\text { enforcement }\end{array}$ & $\begin{array}{l}\text { Days for } \\
\text { contract } \\
\text { enforcement }\end{array}$ & $\begin{array}{l}\text { Procedures in } \\
\text { contract } \\
\text { enforcement }\end{array}$ & $\begin{array}{c}\text { Composite contract } \\
\text { enforcement } \\
\text { institutions }\end{array}$ \\
\hline $\mathrm{N}$ & 46 & 39 & 38 & 28 & 62 & 60 & 60 & 60 \\
\hline $\mathrm{R}^{2}$ & 0.62 & 0.62 & 0.62 & 0.47 & 0.47 & 0.41 & 0.48 & 0.54 \\
\hline
\end{tabular}


Table 9: Conditioning variables

\begin{tabular}{|c|c|c|c|c|c|c|c|c|}
\hline & \multicolumn{8}{|c|}{ Dependent variable: Growth 1995-2005 } \\
\hline & $(9.1)$ & $(9.2)$ & $(9.3)$ & $(9.4)$ & $(9.5)$ & $(9.6)$ & $(9.7)$ & $(9.8)$ \\
\hline InitInc & $\begin{array}{c}-1.367 \\
(2.89)^{* * *}\end{array}$ & $\begin{array}{c}-1.559 \\
(3.33)^{* * *}\end{array}$ & $\begin{array}{c}-1.502 \\
(2.94)^{* * *}\end{array}$ & $\begin{array}{c}-2.159 \\
(3.71)^{* * *}\end{array}$ & $\begin{array}{c}-2.228 \\
(4.00)^{* * *}\end{array}$ & $\begin{array}{c}-1.708 \\
(3.07)^{* * *}\end{array}$ & $\begin{array}{c}1.527 \\
(2.84)^{* * *}\end{array}$ & $\begin{array}{c}-1.545 \\
(3.01)^{* * *}\end{array}$ \\
\hline InvPrice & $\begin{array}{l}-0.024 \\
(374) * * *\end{array}$ & $\begin{array}{l}-0.024 \\
3(65) * * *\end{array}$ & $\begin{array}{l}-0.024 \\
(3.40) * * *\end{array}$ & $\begin{array}{l}-0.019 \\
(2.62) * *\end{array}$ & $\begin{array}{l}-0.019 \\
(2.0) * *\end{array}$ & $\begin{array}{l}-0.022 \\
(294) * * *\end{array}$ & -0.024 & -0.017 \\
\hline LifeExp & $\begin{array}{l}0.011 \\
(0.23)\end{array}$ & $\begin{array}{l}0.018 \\
(0.39)\end{array}$ & $\begin{array}{l}0.036 \\
(0.71)\end{array}$ & $\begin{array}{c}0.098 \\
(1.91)^{*}\end{array}$ & $\begin{array}{c}0.116 \\
(2.26)^{* *}\end{array}$ & $\begin{array}{l}0.059 \\
(1.16)\end{array}$ & $\begin{array}{l}0.045 \\
(0.84)\end{array}$ & $\begin{array}{l}0.055 \\
(0.94)\end{array}$ \\
\hline Trust & $\begin{array}{c}14.495 \\
(3.41)^{* * *}\end{array}$ & $\begin{array}{c}15.015 \\
(3.51)^{* * *}\end{array}$ & $\begin{array}{c}16.511 \\
(3.64)^{* * *}\end{array}$ & $\begin{array}{c}13.684 \\
(3.04)^{* * *}\end{array}$ & $\begin{array}{c}13.208 \\
(2.95)^{* * *}\end{array}$ & $\begin{array}{c}16.574 \\
(3.39)^{* * *}\end{array}$ & $\begin{array}{c}15.378 \\
(2.98)^{* * *}\end{array}$ & $\begin{array}{c}14.258 \\
(2.81)^{* * *}\end{array}$ \\
\hline Inst & $\begin{array}{c}7.951 \\
(4.60)^{* * *}\end{array}$ & $\begin{array}{c}8.790 \\
(5.13)^{* * *}\end{array}$ & $\begin{array}{c}9.085 \\
(4.87)^{* * *}\end{array}$ & $\begin{array}{c}9.117 \\
(4.76)^{* * *}\end{array}$ & $\begin{array}{c}9.620 \\
(5.25)^{* * *}\end{array}$ & $\begin{array}{c}9.124 \\
(4.42)^{* * *}\end{array}$ & $\begin{array}{c}8.153 \\
(3.43)^{* * *}\end{array}$ & $\begin{array}{c}7.366 \\
(3.26)^{* * *}\end{array}$ \\
\hline Trust*Inst & $\begin{array}{l}-12.732 \\
(2.61)^{* *}\end{array}$ & $\begin{array}{l}-12.986 \\
(2.64)^{* *}\end{array}$ & $\begin{array}{l}-14.820 \\
(2.85)^{* * *}\end{array}$ & $\begin{array}{l}-12.227 \\
(2.40)^{* *}\end{array}$ & $\begin{array}{l}-11.923 \\
(2.36)^{* *}\end{array}$ & $\begin{array}{l}-14.969 \\
(2.63)^{* *}\end{array}$ & $\begin{array}{l}-13.375 \\
(2.29)^{* *}\end{array}$ & $\begin{array}{l}-12.179 \\
(1.86)^{*}\end{array}$ \\
\hline Constant & $\begin{array}{c}9.468 \\
(4.31)^{* * *}\end{array}$ & $\begin{array}{c}9.820 \\
(4.21)^{* * *}\end{array}$ & $\begin{array}{c}7.699 \\
(3.56)^{* * *}\end{array}$ & $\begin{array}{c}8.968 \\
(4.05)^{* * *}\end{array}$ & $\begin{array}{c}7.710 \\
(3.13)^{* * *}\end{array}$ & $\begin{array}{c}7.775 \\
(3.46)^{* * *}\end{array}$ & $\begin{array}{c}7.898 \\
(3.27)^{* * *}\end{array}$ & $\begin{array}{c}7.097 \\
(2.55)^{* *}\end{array}$ \\
\hline $\begin{array}{l}\text { Control } \\
\text { Variable(s) }\end{array}$ & $\begin{array}{c}\text { Ethnic } \\
\text { Fractionalization }\end{array}$ & $\begin{array}{c}\text { Linguistic } \\
\text { Fractionalization }\end{array}$ & $\begin{array}{c}\text { Religious } \\
\text { Fractionalization }\end{array}$ & $\begin{array}{c}\text { Ethnic } \\
\text { Polarization }\end{array}$ & $\begin{array}{l}\text { Religious } \\
\text { Polarization }\end{array}$ & State Antiquity & $\begin{array}{l}\text { Colonial } \\
\text { dummies }\end{array}$ & $\begin{array}{c}\text { Legal Origin } \\
\text { Dummies. }\end{array}$ \\
\hline $\begin{array}{l}\text { Coefficient of } \\
\text { control }\end{array}$ & $\begin{array}{c}-1.474 \\
(2.28)^{* *}\end{array}$ & $\begin{array}{c}-1.183 \\
(2.04)^{* *}\end{array}$ & $\begin{array}{c}-0.467 \\
(0.71)\end{array}$ & $\begin{array}{c}-0.340 \\
(0.61)\end{array}$ & $\begin{array}{l}0.596 \\
(1.07)\end{array}$ & $\begin{array}{c}-0.284 \\
(0.42)\end{array}$ & - & - \\
\hline $\begin{array}{l}\mathrm{N} \\
\mathrm{R}^{2}\end{array}$ & $\begin{array}{c}46 \\
0.73\end{array}$ & $\begin{array}{c}46 \\
0.73\end{array}$ & $\begin{array}{c}46 \\
0.70\end{array}$ & $\begin{array}{c}41 \\
0.74\end{array}$ & $\begin{array}{c}41 \\
0.74\end{array}$ & $\begin{array}{c}45 \\
0.69\end{array}$ & $\begin{array}{c}46 \\
0.70\end{array}$ & $\begin{array}{c}46 \\
0.72\end{array}$ \\
\hline
\end{tabular}

Notes: Dependent variable in all regressions: Absolute value of t statistics in parentheses, $*$ significant at $10 \%$; ** significant at $5 \%$; *** significant at $1 \%$. The colonial and legal origin dummies can be found in Table 2. 
Figure 1: The investment game

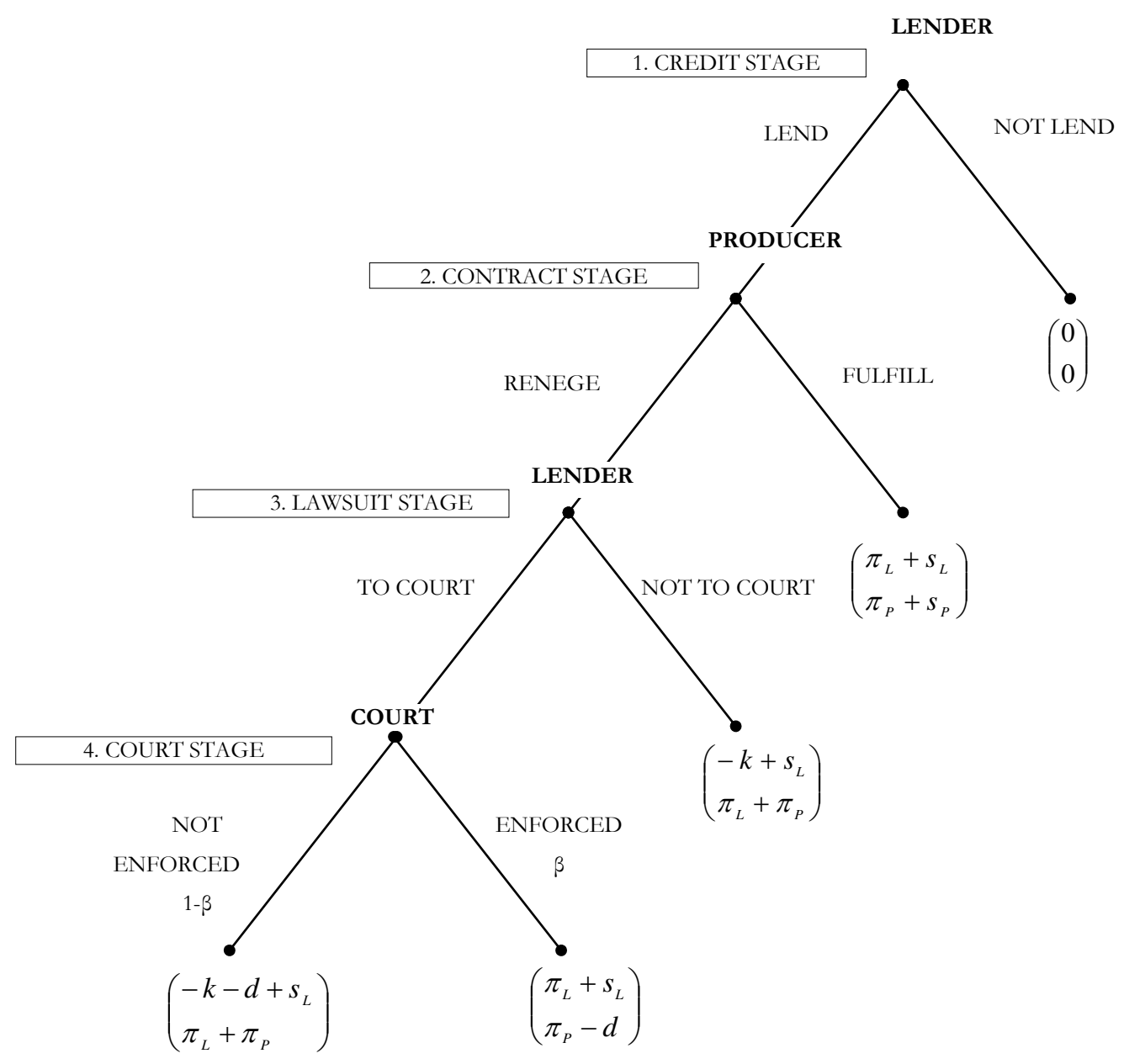


Figure 2: Investment game equilibria under varying strengths of court institutions and social capital.

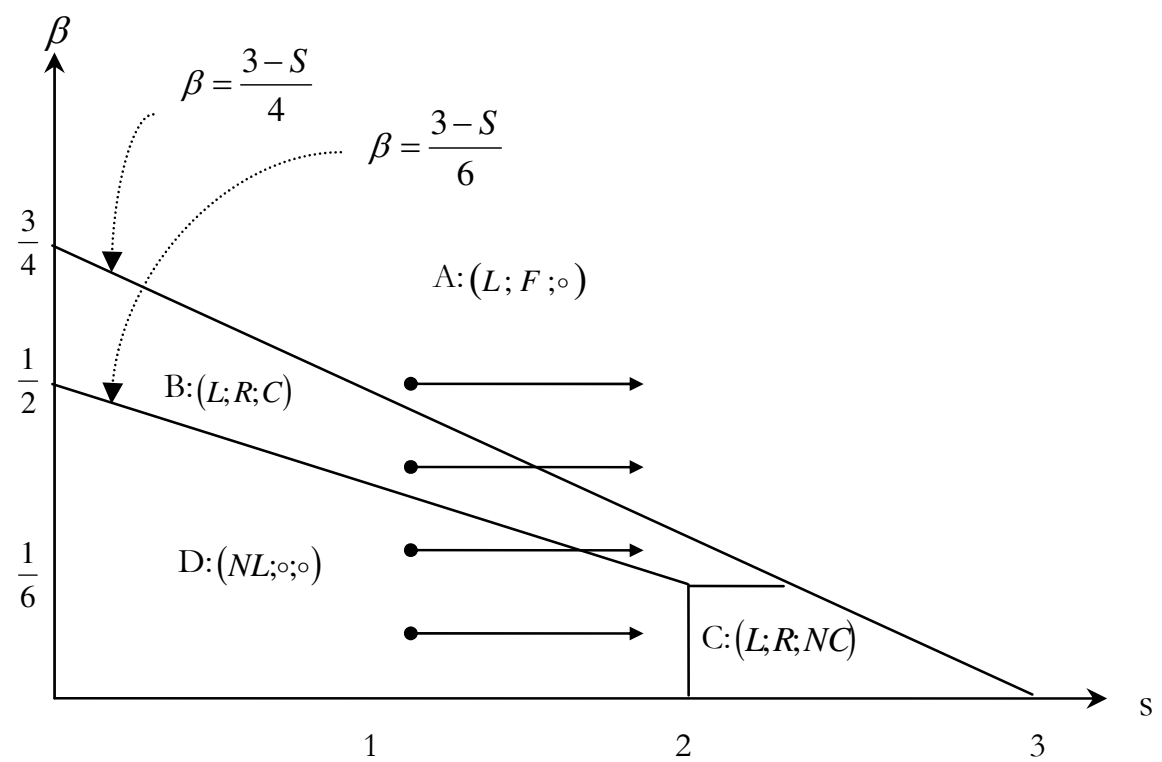

Note: The figure is based on the results in Solutions, assuming the following parameter values: $\pi_{\mathrm{L}}=\pi_{\mathrm{P}}=3$, $k=2, d=1, s_{L}=s_{P}=s$. 